\title{
periferia
}

Número 8, junio 2008

www. periferia.name

\section{Anthropology and the 'War on Terror'. Analysis of a complex relationship}

\author{
Addaia Marrades Rodriguez - Departament d'Antropologia social I cultural - UAB ${ }^{1}$ \\ “The tradition of the oppressed teaches us that 'the state of emergency' in which we live is not the \\ exception but the rule". Walter Benjamin, Theses on the Philosophy of History.
}

\begin{abstract}
The 9/11 events in 2001 and the obsession of Western intelligence agencies to counteract the radical Islamist threat have once more put anthropology in the front line. Indeed, in the current context of 'War on Terror', anthropology methods and skills are in demand, but the engagement of the discipline with the military is creating heated debates at the heart of it. In this paper, I analyse the present call from a historical perspective and I highlight its particularities especially in relation to the emerging security-development nexus. In order to do so, I focus on programmes appeared in the USA (Pat Roberts Intelligence Scholars Program) and the UK (Combating Terrorism by Countering Radicalisation). Both programmes employ anthropologists and other social scientists aiming to grasp a better understanding of what military agencies think the enemy is in order to combat it more efficiently. Using internet resources and debates appeared in journals and professional associations extensively, this paper analyses the engagement of anthropology and the military in the twenty-first century taking into account the consequences this relation has outside the discipline but also inside it.
\end{abstract}

Key-words: anthropology of war.

\section{Resumen}

Los acontecimientos del 11 de septiembre de 2001 y la obsesión de las agencias de inteligencia occidental de contrarrestar el islamismo radical ha puesto una vez más a la antropología en primera línea. Ciertamente, en el contexto actual de la "Guerra contra el Terror", se demandan los métodos y habilidades antropológicas, pero la incorporación de la disciplina con los militares está creando acalorados debates en su seno. En este artículo, se analiza esta cuestión desde una perspectiva histórica y se ponen de manifiesto sus particularidades especialmente en relación al nexo emergente seguridad-desarrollo. Para ello, nos centramos en los programas aparecidos en los EUA (Pat Roberts Intelligence Scholars Program) y el Reino Unido (Combating Terrorism by Countering Radicalisation). Ambos programas emplean antropólogos y otros científicos sociales intentando obtener un mayor conocimiento de cuál es el enemigo de las agencias militares con el objetivo de combatirlo de una forma más eficiente. Mediante el uso de recursos de internet y los debates aparecidos en las revistas y las asociaciones profesionales de una forma extensiva, este artículo analiza la vinculación de la antropología y los militares en el siglo XXI, tomando en consideración de las consecuencias de esta relación fuera de la disciplina pero también en su interior.

Palabras clave: antropología de la guerra. 


\section{periferia}

Número 8, junio 2008

www.periferia. name

\section{I ntroduction}

The aim of this paper ${ }^{1}$ is to critically analyse the complex relationship between anthropology and the so-called 'War on Terror' by emphasising the consequences it has and it might have for the discipline.

The 9/11 events in 2001 were decisive for the development of a "counteracting crusade" (Wax 2003: 23) to protect the civilised West from what now appears to be its main enemy: radical Islamism. Since then, the most visible consequences of USA government led 'War on Terror' have been the so-called Operation Enduring Freedom started in October 2001 in Afghanistan, and the so-called Operation Iraqi Freedom, which started in March 2003. None of these wars, as they are popularly labelled, are considered to have finished yet.

The loss of legitimacy of the USA strategy between a great deal of its former supporters $^{2}$ seems not to worry the Bush administration but for the electoral consequences it might have. This has evidenced the need of the 'War on Terror' theorists to regain support for their principles, something they have attempted to do by appealing to the lack of security that characterises today's world and to the good intentions behind their theses. In the Azores summit, celebrated in March 2003, President G. W. Bush identified the 'War on Terror' as the first war of the twenty-first century (Spence 2005) in which, following his rhetoric, the USA leads the battle against the enemies of democracy for the benefit of the whole world. Critics, however, emphasise this battle is not in the name of democracy but of neoliberalism.

\footnotetext{
1 The first version of this article was written in January 2007 as a term paper for the course "Anthropologists in development" within the MA "Anthropology of Development and Social Transformation" of the University of Sussex (England). In January 2008 it was published in the website of the anthropology department of the same university (http://www. sussex.ac.uk/anthropology/1-2-3-31.html). The current version in Periferia has been updated and adapted to the present context.

2 It is worth remembering George W. Bush's sending of 21.500 additional soldiers to I raq in January 2007 was approved against the will of the Democrats and the moderate wing of the Republican Party.
} 


\section{periferia}

Número 8, junio 2008

www. periferia. name

Actions taken in the USA to improve intelligence gathering after the 9/11 attacks emphasise two aspects: the need to improve intelligence analysts' work, and the need to present USA's interventions as a just response to chaos. In order to satisfy both requirements, USA military apparatus has insistently called for the commitment of social scientists to their endeavours in the name of patriotism and security. Independently of the outcome of such calling, which has been diverse, this has lead to an increasing influence of the 'War on Terror' thesis on the academic life. Furthermore, the recognition that anthropology's methods and skills are especially in demand in wartime has once more posed the discipline in a central place within the social sciences. Thus, eternal debates at the heart of anthropology around the ethics of spying and its social responsibility have revived.

The implication of anthropology with security agendas has already been intensely discussed, particularly in the light of the engagement of a number of anthropologists with the military during the Cold War. Despite the current political context being significantly different, the security paradigm is increasingly reemerging since the 9/11 episode. This has been more obvious in the USA, although the UK is not far behind. As a result, there has been a dramatic appearance of a security-development nexus in the discipline, which has had grave consequences.

The prioritisation of security over development has become dangerously dominant as aid is being militarised. There has been a shift in aid priorities from poverty reduction to fighting international terrorism - especially Islamic terrorism-, which means aid is being allocated for political ends rather than genuine needs. Besides, it seems clear that it is not the security of the poor what matters today, but it is that of the West instead (Beall, Goodfellow and Putzel 2006). For anthropology, the security-development nexus raises a number of moral and ethical dilemmas concerning the integrity of the discipline as a whole. Intelligence agencies and governments claim they need the anthropological analysis to improve counterinsurgency and national security, but anthropologists have to seriously consider what this link means for the future of the discipline. Although past wartime anthropological connections with the military could have been seen as appropriate for their times (Price 2002b), today the link raises many more complex and 


\section{periferia}

Número 8, junio 2008

www. periferia.name

problematic issues.

In this paper, I will start with a brief history of the past involvement of anthropologist with security agendas in order to contextualise the current calling for a direct engagement of anthropologists with the 'War on Terror'. I will then examine USA Pat Roberts Intelligence Scholars Program and the UK Combating Terrorism by Countering Radicalisation programme putting special attention to the opposed opinions anthropologists have held around them and around the broader issue of collaborating with the military. Following that, I will explore the main dilemmas the commitment raises in the discipline especially in relation to the ethical codes of the $\mathrm{AAA}^{3}$ and the $\mathrm{ASA}^{4}$. The concluding remarks will highlight the main arguments discussed in the paper and will bring up some ideas in order to design new committed and critical anthropologies.

\section{The engagement of anthropology with the 'War on Terror'}

\section{Historical background}

In 1919 Franz Boas wrote a famous letter to The Nation that is still relevant eightynine years later. In it he denounced those anthropologists who during WWI used their profession to serve as spies and defended the ethical calling inherent in anthropology by claiming spying polluted the discipline (Boas 1919). Boas strongly insisted the loyalty of anthropologists to their discipline and to science in general was to be over their patriotism. The AAA, however, disapproved that there was anything wrong with anthropologists using their profession to work as spies and censured him (Price 2002b).

The involvement of anthropologists with the military apparatus during the main wars of the last century is undeniable. Many anthropologists, borrowing Price's words, fought with both books and guns (2002b), and it is worth noting that most

3 American Anthropological Association.

4 Association of Social Anthropologists of the UK and the Commonwealth. 


\section{periferia}

Número 8, junio 2008

www. periferia. name

of them got involved understanding their implication as an ethical responsibility. Under this premise, during WWII there was a widespread application of anthropology to warfare (McFate 2005), and an overwhelming majority of USA anthropologists collaborated with the military, among those "leading students $(\cdots)$ of Boas - such as Margaret Mead, Ruth Benedict and Alfred Kroeber" (Wax 2003: 23). In the case of Britain, important names such as Bateston, Evans-Pritchard and Leach fought as combatants and applied their anthropological skills in the service of war. As Price points out in the case of Bateston, these skills were very useful but equally troubling (2002c: 3 ).

Although some anthropologists such as Bateston himself recognised they eventually regretted their attitude (Price 2002c), the Cold War brought many more opportunities for anthropologists eager to collaborate with the intelligence apparatus. This was especially obvious in the USA, where funding allocated to counter-insurgency programs grew dramatically in the light of the anti-communist crusade (McFate 2005). The USA Department of Defence realised the new scenario, characterised by enemies organised as guerrillas and not as regular armies, required revising conventional military techniques, and for the first time this pushed it to consider the social and cultural conditions that could motivate the appearance of these armed groups in order to successfully combat them. With this strategy in mind, in 1956 it created the Special Operations Research Office (SORO), which was established as a virtually independent research institute with its headquarters at the American University (Washington D.C.). However, its links with the USA military apparatus were obvious, as through the Counter-insurgency Information Analysis Center a number of anthropologists and other social scientists did clandestine research on counter-insurgency (Solovey 2001).

From that moment on, social sciences in general and anthropology in particular had an important role to play in the national and international politics of the USA. Not surprisingly, USA intelligence agencies became the main funding bodies of leading social science projects carried out from WWII to the 1960s (Solovey 2001). One of greatest importance was the infamous Project Camelot, an ambitious research programme established in 1964 by the SORO the aim of which was to obtain 


\section{periferia}

\section{Número 8, junio 2008}

www. periferia. name

primary data on so-called Third World revolutionary movements in order to oppose them more effectively (Solovey 2001, McFate 2005). The project counted with a multidisciplinary team of social scientists from the most prestigious institutions of the USA ${ }^{5}$ under the leadership of Rex D. Hopper, a Brooklyn College specialist in Latin America (Solovey 2001). Initially established for 4 years with an enormous budget of USA $\$ 6$ million, the project planned to carry out secret fieldwork in a number of countries ${ }^{6}$ starting with Chile, but when this confidential information was filtrated it created a great scandal. The consequences were so grave that USA Secretary of Defence Robert McNamara had to cancel the project in 1965 while still within the planning phase (McFate 2005).

Also in the late 1960s, several anthropologists and other social scientists worked on classified projects designed to stabilise the government of Thailand gathering data, among other things, on villagers' attitudes towards communism (Wakin 1992). Although is not known for certain, it is believed that the Thai military used this information to decide where to conduct counter-insurgency operations or carry out development projects to encourage tribal villages to remain loyal to the government (McFate 2005).

As a result of Project Camelot and the Thai scandal "heated debates took place within the AAA's Committee on Ethics" (McFate 2005: 36), which tightened its ethical rules for researchers accordingly. In the 1971 version of its ethical code the AAA strongly prohibited secret research (AAA 1971) but remarkably, references to secret-clandestine research had been dropped off by the 1990 revised version (AAA 1990, Fluehr-Lobban 1991).

In 1995 Felix Moos, a University of Kansas' anthropologist who is a fervent defender of the collaboration between anthropologists and the military in the interest of national defence and security, claimed for the revision of the 1990 code of ethics of the AAA. Moos strongly argued that anthropologists "should be

5 Such as California-Berkeley, MIT, John Hopkins, Princeton, Columbia, Michigan, Pittsburgh, Virginia or Standford.

6 Project Camelot was planning to do research in countries such as Bolivia, Colombia, Paraguay, Peru, Venezuela, Iran and Thailand. 


\title{
periferia
}

\author{
Número 8, junio 2008
}

www.periferia.name

permitted -indeed, should feel a duty- to conduct classified research that might help the U.S. government understand global conflicts" (quoted in Glenn 2005), and he suggested training college students as analysts for intelligence agencies. Moos thought that if intelligence agencies could not readily get anthropologists to work for them, at least they could create them. At that time, however, his claim was mostly unpopular.

Nevertheless, Moos' plea was not totally new, as similar programmes such as the one he advocated for already existed in the USA. The National Security Education Program (NSEP), for example, was created just after the 1991 Persian Gulf War by the then Senate Intelligence Committee chairman David Boren. The NSEP funds USA students to study world regions critical to USA interests and the future security of the nation. NSEP scholars and fellows get funding in exchange for a labour commitment in government agencies related to foreign policy, but only a small fraction of the recipients become intelligence analysts (Glenn 2005). The programme, therefore, was not producing the numbers needed.

\section{Current context}

After the 9/11 attacks in 2001 and in the light of the wars in Afghanistan and Iraq, Moos insisted further on his proposal. The 9/11 events revealed that USA intelligence weaknesses were not just embarrassing but catastrophic (Glenn 2005), and within this framework the callings for anthropologists to be active agents on the 'War on Terror' in order to improve USA intelligence gathering multiplied. AlQaeda is nowadays the embodiment of the new global and diffused enemy, and the new reality USA forces are facing has made evident that "U.S. technology, training, and doctrine designed to counter the Soviet threat are not designed for lowintensity counterinsurgency operations where civilians mingle freely with combatants in complex urban terrain" (McFate 2005: 24).

In order to respond to this changing reality, the USA and the UK respectively launched two demand-driven programmes, the Pat Roberts Intelligence Scholars Program and the Combating Terrorism by Countering Radicalisation programme, which have had very different results. In the USA, since April 2004, dozens of 


\title{
periferia
}

\author{
Número 8, junio 2008
}

www. periferia. name

analysts-in-training have entered USA universities to burnish their skills in certain languages, cultures, and technical fields that USA intelligence agencies deem to be critically important. In the UK, on the contrary, the first programme was object of such substantial critique that it was cancelled before it even started. Despite not targeting students of anthropology specifically, both programmes recognise that anthropological skills and methods are on demand, and participants are expected to use the techniques of fieldwork to gather political and cultural information. The literature available on these programmes is mainly accessible on-line, and it is much more abundant in the case of PRISP.

\section{Pat Roberts I ntelligence Scholars Program (USA)}

USA Pat Roberts Intelligence Scholars Program (PRISP) is the brainchild of Professor Felix Moos and gets its name from Senator Pat Roberts, a Kansas Republican who is chair of the Senate Select Committee on Intelligence.

The PRISP is a demand-driven and decentralised military intelligence project that is expected to improve the analytic depth and quality of the Intelligence Community (IC). First established in 2004 as a pilot program of two years of duration, it is assumed it has been evaluated through a classified Congress report. Its purpose is to help 15 different agencies of the USA IC, and not just the $\mathrm{CIA}$ as sometimes it is wrongly assumed, to recruit and train analysts with critical linguist or scientific skills that the labour market does not readily provide. These critical skills are determined by intelligence agencies and include areas in which the analytical capabilities of the IC are currently deficient or are likely to be deficient (Nuti n.d).

The PRISP is funded by the USA Congress. In 2004 it was allocated USA $\$ 4.0$ million and in 2005 this was increased to USA \$6.0 million allowing it to augment the number of scholars employed per year, initially set in 150 . The programme is limited to USA citizens and it is not restricted to anthropology students, although participants need to meet requirements that have to do with the skills intelligence agencies are looking for. It is open to undergraduate and graduate students as well as to individuals in the private sector, depending on the preferences of each IC component. 


\title{
periferia
}

\author{
Número 8, junio 2008
}

www. periferia. name

The PRISP funds individuals by offering scholarships or stipend benefits, depending on whether they already have the requested skills or still have to acquire them. Participants receive USA $\$ 25,000$ a year with a maximum of USA $\$ 50,000$ over two years. In exchange, they commit to serve as intelligence analysts in a paid internship "mostly in the headquarters of a component intelligence agency" (Nuti n.d.) for at least $1 \frac{1 / 2}{2}$ times the period of scholarship support.

Participants expected to finish their academic programs might be affiliated with a particular component intelligence agency. The PRISP, however, specifies him or her "does not work for the agency while pursuing studies" (Nuti n.d.). It also emphasises intelligence analyst positions are not covert but intelligence agencies have their own policies on disclosure, thus the PRISP does not facilitate any public list of participants. Some agencies require that PRISP students do not disclose while others do not and leave the matter to the discretion of the student. In any case, participants are strongly recommended "to exercise prudence in disclosing their affiliations and roles primarily because identification may invite harassment" (Nuti n.d.). The $\mathrm{ClA}$, for example, suggests participants not to acknowledge their affiliation arguing the interest of other people in it might not be benign ( $\mathrm{ClA}$ n.d.).

\section{Combating Terrorism by Countering Radicalisation (UK)}

In July 2006, the British Foreign and Commonwealth Office (FCO) launched a UK f1.3-million research initiative co-sponsored by the Economic and Social Research Council (ESRC) and the Arts and Humanities Research Council (AHRC) entitled Combating Terrorism by Countering Radicalisation. The aim of the project was to analyse extremist Islamist groups present in six regions ${ }^{7}$ and five countries $^{8}$ to grasp a better understanding of their functioning in order to oppose them more efficiently.

The fact that the research programme was not openly advertised and that the Joint Terrorism Analysis Centre of the UK Security Service participated in its design (Houtman 2006) raised many criticisms, as it was seen as a direct attack to the

7 Europe, Central Asia, South Asia, Southeast Asia, North Africa and the Persian Gulf.

8 J ordan, Nigeria, Somalia, Sudan and Turkey. 


\section{periferia}

Número 8, junio 2008

www. periferia. name

reputation of British council-funded research in terms of its independency and quality. Mundy argued the programme entailed a series of specific intelligencedriven questions and took for granted the existence of a link between Islam, radicalisation and terrorism, although it avoided defining these concepts (quoted in Baty 2006). Academics were asked to "scope the growth in influence and membership of extremist Islamist groups in the past 20 years", "name key figures and key groups", and "understand the use of theological legitimisation for violence" among other issues. Some of the core topics included "radicalisation drivers and counterstrategies in each of the countries studied" and "future trends likely to increase/decrease radicalisation" (quoted in Baty 2006).

The project "provoked a furious response from academics", mainly anthropologists, "who claimed it was tantamount to asking researchers to act as spies for British intelligence" (Baty 2006). James Fairhead, who works for the ESRC's Strategic Research Board and on its International Committee, declared it is appalling that these proposals were not discussed in any of these committees (quoted in Houtman 2006). Opposition to the project grew significantly after the plans were published in the Times Higher Educational Supplement. As a result, it was withdrawn before its closing date on November $8^{\text {th }} 2006$.

Despite this, the ESRC announced it would work to draft a new call within its key research challenge, the New Security Challenges Programme, a five-year programme which began in 2003 that currently sponsors projects in order to better respond to the security challenges the post-Cold War and post-9/11 globalised world is facing. The revised research programme, also in partnership with the FCO and the AHRC, was publicly advertised in 2007 and it has more funding available than the first one (ERSC 2006). In relation to that, the ERSC highlights it is "committed to supporting research that is relevant to policy as well as independent and academically rigorous" (Sooben 2006: 3) emphasising quality, relevance and independence. Although the second programme is re-framed in terms of "global uncertainties" and not only the 'War on Terror', it "effectively reduces issues such as poverty, political dissent and even environmental degradation to simple matters of security" (Osella 2008). Furthermore, the second Combating Terrorism by 


\section{periferia}

Número 8, junio 2008

www. periferia. name

Countering Radicalisation programme still focuses mainly on Muslims and Islam and assumes that radicalism, apart from being thought as bad and inherently violent, is endogenous to Islam.

\section{Different positions within the discipline}

In all programmes anthropology is needed in a very specific way, namely as a means to improve the knowledge of the sociocultural background of the enemy in order to design better and more efficient counter-insurgency strategies. According to this idea, Price points out "military and intelligence agencies are now seeking to weaponize anthropological knowledge for their own ends at levels not seen since the Second World War" (2008). Indeed, some anthropologists have contributed their skills to the USA Army's new Counterinsurgency Field Manual, as well as to the so-called Human Terrain Teams, military advisory units designed and joined by anthropologists (Price 2008).

Programmes such as the ones analysed in this paper are framed in a particular rhetoric of patriotism and democracy that emphasises the duty of collaborating with national military intelligence agencies in order to join the global fight against terrorism. Supporters of the collaboration thesis often argue USA is indeed at war and "the existing cultural divide between academe and the intelligence community has become a critical, dangerous and very real detriment to our national security at home and abroad" (Moos 2005: 25). They maintain today's world is more complex, dangerous and violent (Moos 2005: 25), and recognise the value of anthropological insights, as "winning hearts and minds requires understanding the local culture" (McFate 2005: 25). However, critics suspect the mantra of the war and the paranoia created in the aftermath of the 9/11 attacks hide a security situation that is not as pressing as to justify the training of spies under these methods (Nas 2005, Gusterson 2005b).

Collaborators seem not to understand why "there are few anthropologists either available or willing to play in the same sandbox with the military" (McFate 2005: 27) if, as Moos says, many were already committed to helping the military during WWI and WWII (2005). This disregards the current lacking of a strong national 


\section{periferia \\ Número 8, junio 2008 \\ www. periferia. name}

consensus in the USA (Gusterson 2005b) and the UK, where the longer the war lasts, the higher the number of people against it is. Moreover, as some collaborators recognise, "military applications of cultural knowledge might be distasteful to ethically inclined anthropologists" (McFate 2005: 37). Nevertheless, they exhort anthropologists to leave their ivory tower and experience the real world (McFate 2005, Dean 2005) emphasising the PRISP offers a great opportunity to USA students "willing to pursue advanced education in order to serve as intelligence analysts" (Dean 2005: 21). From the other side of the debate, anthropologists bring attention to the fact that "the $\mathrm{ClA}$ isn't some clearing house of cultural information, it employs torturers, kidnappers and murderers" (Price 2006a: 21), and that it has a long history of "destabilising democratic governments, committing human rights abuses and suppressing popular movements" (Baty 2005). Working for it or for similar agencies may be a source of ethical dilemmas for most anthropologists, also because as Keenan (2006) shows, intelligence agencies often manipulate information for their interests.

Supporters often point out that concerns from anthropologists are misplaced, as PRISP and CTCR are intended to address the current ignorance on foreign lands. However, this seems a rather naïve approach, as it overlooks the uses the intelligence apparatus will make of the information gathered by anthropologists. Supporters also note that "an engaged dialogue" between anthropologists and the intelligence apparatus would not violate any academical or anthropological norms (Dean 2005: 21), but critics base their arguments on the grounds that collaboration with intelligence agencies violates the ethical codes of both the profession and the academy (Gusterson 2005a). Accordingly, they argue "any funding programme should be accepted only on the condition that it observes the codes developed by the anthropological scientific community" (Nas 2005: 20) and remind that collaboration under the terms of the PRISP and CTCR goes against the principle of openness of the academy (Gusterson 2005b), as both encourage clandestine research. Price argues in the same terms Boas (1919) used long ago that "secrecy is the key. Secrecy pollutes environments of scientific or humanistic enquiry. Secrecy undermines all anthropologists' relationships with the individuals and 


\section{periferia}

Número 8, junio 2008

www. periferia. name

communities we study" (Price 2002c: 21). Indeed, it undermines the basic principle of informed consent and violates informants' right to know the aims and results of the research, which in that case would neither be transparent nor published. Critics strongly argue that secrecy and science are not compatible, as "healthy academic environments need openness because they (unlike the $\mathrm{ClA}$ ) are nourished by the self-corrective features of open disagreement, dissent, and synthetic-reformulation" (Price 2005a). They recognise that if the link with the ClA was made clear "the likelihood that our hypothetical ethnographer would find many interlocutors is minimal which is, of course, why the $\mathrm{ClA}$ wants its researchers to keep their affiliations secret" (Gusterson 2005a: 26). Furthermore, in a context where the international reputation of the UK and USA are poor, collaboration can seriously endanger the lives of the researchers. Secrecy, therefore, is an effective way of covering up ignorance and doubt (Gledhill 2006), although collaborators emphasise its aim is not to protect hidden agendas but to oppose the enemy more efficiently.

Secrecy also creates mistrust of anthropological fieldwork (Glenn 2005) destroying opportunities for future fieldworkers and relations of trust built up with their informants, as anthropologists can no longer ensure that research does not harm the safety, dignity or privacy of the people studied. Fardon adds that both PRISP and CTCR will have implications for anthropology across the world and will foster suspicion also between colleagues (quoted in Baty 2005). This is very clear in the case of the PRISP, as despite Moos' will neither the list of participants (Glenn 2005) nor the list of universities (Gusterson 2005b) have been made available. Some of the agencies within the PRISP framework require participants to keep their involvement secret an others do not, but assuming people will invariably disclose whatever they are not required to keep secret is wrong (Fardon 2005). This has raised concerns within anthropologists, worried PRISP participants in undergraduate programs might inform on professors critical with USA foreign policies, as it is believed "some PRISP scholars are being prepared for covert careers, and are instructed to hide their links to US intelligence while at university" (Gusterson 2005b: 21). 


\section{periferia}

Número 8, junio 2008

www. periferia. name

A common argument supporters of the collaboration thesis use is that of anthropologists being the best professionals for the role, as "political policy and military operations based on partial and incomplete cultural knowledge are often worse than none at all" (McFate 2005: 24). Some of them go even further by claiming that "perhaps their advice at an earlier stage would have reduced the need for the all-out wars that evolved" (Sebag-Montefiore 2006: 21). However, the rhetoric around the greatness of the discipline is empty, as Price notes when he says "they don't care about us. They don't care about our research, they don't care about the people we study, they don't care about our well-being, they don't care about our reputation. We need to care about it, and we need to distance ourselves from them" (quoted in Glenn 2005). The basic responsibility of anthropologists is to serve rather than to fight and oppress those we study. Following that, Gill suggests that she would oppose the PRISP even if it were more open. "Part of the core notion of anthropology," she says, "is that you won't use your work to undermine or harm your subjects - and it seems to me that going to work for an intelligence agency undermines that commitment" (quoted in Glenn 2005). The systematic collection and analysis of information about the powerless "tends to add more to the power of the potential oppressors than to the ability of the weak to resist" (Whisson 2000: 22), raising infinite potential dangers. As Gledhill says, "if research enables people to identify human beings, there is no guarantee that nothing harmful is going to happen" (quoted in BBC 2005), as the knowledge gathered will not be necessarily used to their benefit. Although they base their calling in a rhetoric of democracy and freedom, unfortunately intelligence agencies have long been known for doing exactly the opposite they wanted to convey (Fardon 2005).

Following the debate, critics claim that anthropologists working with the military will be subjugated to their worldview, whereas supporters argue that their collaboration does not imply blindly acceptance and following of the conservative ideology or political aspirations of the governments they work for. This, however, is a naïve point. The military-driven nature of the research is a clear threat to intellectual independence, as the outcome is often characterised for not being critical and for oversimplifying complex phenomena. Concepts such as terrorism are taken as 


\title{
periferia
}

\author{
Número 8, junio 2008
}

www.periferia.name

given and remain "strategically undefined" (Price 2002a: 3), and polemic issues such as the relation between Islamism and terrorism are not discussed but taken for granted. As a result, there is a real danger of people opposing the worldview behind the 'War on Terror' thesis of being labelled terrorists (Price 2002a: 4). Supporters often dismiss that the rhetoric of humanitarianism hides direct political intervention based on patronising conceptions, and the militarised nature of the research seriously endangers its independence. As Gusterson puts it, anthropology seems to go backwards because the current crisis shows it has not learned from the mistakes made in the 1960s (2005b). Acknowledging this, Gledhill suggests "the best way to respond to Professor Moos is $(\cdots)$ to use our knowledge and experience to show that there are other, and much better, ways to foster the production of knowledge that can contribute to promoting peace and security on a planetary scale" (2006).

\section{Dilemmas for anthropology and development}

The links between anthropologists and colonialism are well documented ${ }^{9}$, but the lack of analyses of the relationship between anthropologists and their contributions to the wars of the $20^{\text {th }}$ and $21^{\text {st }}$ centuries is appalling. Price, one of the most outspoken critics, argues these contributions raise serious ethical and practical questions and are often downplayed (2002b). In order to avoid what Gledhill defines as rather ironic dejá vu sensations (2006) anthropologists should "confront the nature and scope of past anthropological contributions to warfare" and counterinsurgency (Price 2002b: 14) confronting the "general hesitancy" within the discipline to take history seriously (Price 2002c: 17). It is imperative, therefore, to critically evaluate and speak out the dangers the 'War on Terror' is posing on people and anthropology (Price 2002a).

The ethical codes of the different national associations of anthropologists offer valuable guidelines from which to start thinking on ethical issues, but they are "often based on situational ethics and, when the values they are based on come

9 By scholars such as Talal Asad, Kathleen Gough, Dell Hymes, Adam Kuper, and George Stocking among others. 


\section{periferia}

Número 8, junio 2008

www. periferia. name

into conflict, scholars are often left to make the best of a bad situation" (Nas 2005: 20). They are informative but not prescriptive, and cannot give rapid responses to new changing contexts. In order to discuss ethical dilemmas promptly and publicly, however, the AAA and the ASA have both used internet resources extensively. The ASA started its praised Ethics blog with a sharp unofficial critique of PRISP by Gledhill (2006). Although the aim of the blog format was to facilitate comprehensive reflections on these dilemmas and more inclusive ways of tackling them, it has to be said during 2007 it hardly had any continuity ${ }^{10}$. Similarly, the AAA's Ethical Currents Case Studies has often been criticised for being too weak. In January 2008, however, a new ASA blog was put into action with the idea of engaging the community of anthropologists in open discussions on front-row topics within the discipline. It is symptomatic that the first topic to be discussed was "Counterinsurgency" and the relation between anthropology and the "War on Terror'.

Professional associations, therefore, play a central role in the current situation. In the case of PRISP, for example, the ASA has opposed the plan acknowledging that many USA anthropology students regularly study in the UK. Gledhill, the Chair of the ASA, told the Times Higher Education "this scheme not only threatens the personal safety of all anthropologists conducting fieldwork in more turbulent parts of the world, irrespective of their nationality, but would diminish the contribution that anthropological research can make to the solution of global problems" (quoted in Baty 2005). As a result, the ASA's code of ethics is being revised in order to encompass this and similar initiatives.

In the case of the USA counterpart, the AAA has also been positioning itself against the engagement of anthropologists with the 'War on Terror'. On its 2006 Business Meeting, the AAA passed two resolutions on the occupation of I raq and on torture raising important issues surrounding covert research and the irresponsible use of research findings, and calling for transparency and accountability. This meeting, defined as "historical" by some scholars (Houtman 2006), was seen as the starting 


\title{
periferia
}

\author{
Número 8, junio 2008
}

www. periferia. name

point of a clearer positioning of the AAA against the militarisation of the discipline. Certainly, a year later the AAA issued a strong statement declaring that Human Terrain Teams are "an unacceptable application of anthropological expertise" (2007), and on its 2007 Business Meeting it adopted a resolution "calling for the reestablishment of removed language from the 1971 ethics code that prohibited secret anthropological research" (Price 2008).

Moreover, some anthropologists have organised themselves on the grassroots level to push professional associations to unambiguously position themselves against the militarisation of the discipline. A good example of this is the so-called Network of Concerned Anthropologists created by a group of anthropologists from the USA. who have organised an international "Pledge of Non-participation in Counterinsurgency" (NCA 2008) that is being signed by social scientists around the world.

Anthropologists and their professional associations should analyse carefully the ideas on development that lie behind PRISP and CTCR. All programmes justify intervention and violations of basic human rights in the name of security, and raise attention to the vulnerability of impoverished countries to the penetration of terrorism. However, the reduction of complex issues such as poverty, migration, or development to simple problems of security is clearly trivialising and politicising them (Osella 2008), which is exactly the opposite anthropology aims to do.

Programmes such as PRISP and CTCR understand development as a tool to protect the West, and it is alarming that the subordination of aid to political, economic or military interests has already altered the context in which development aid is framed and implemented (Howell 2006). Clearly, it is not the security of the poor what matters, but the one of the West instead (Beall, Goodfellow and Putzel 2006).

\section{Concluding remarks}

In this paper I have argued that the involvement of anthropologists with the military for the benefit of the 'War on Terror' agenda undermines the discipline as it jeopardises its professional ethics and damages its credibility. 


\section{periferia}

Número 8, junio 2008

www. periferia. name

The spread of neoliberalism during the recent decades has made university autonomy increasingly precarious. Anthropologists have been progressively dependant on private funding, which has brought complex dilemmas to the discipline (Fluehr-Lobban 1991, Gledhill 1994, Caplan 2003). More recently, this has been aggravated by the pressures the military apparatus is posing on anthropology. Programmes such as PRISP and CTCR embody the militarisation of the discipline posing it at the service of the ruling powers, which have radically different objectives. As Houtman says, "such engagement often entails pressure to modify our findings in the light of values that ought to be themselves the subject of in-depth research" (2006: 2), endangering the critical perspective that characterises the discipline. Moreover, PRISP and CTCR are framed within the wider context of the USA-made 'War on Terror', which emphasises the need to use secrecy as a means of protecting Western citizens from global terrorism ${ }^{11}$, although this clearly undermines academic openness.

Within this worldview the "state of exception" becomes the rule, and some scholars argue the militarisation of development and the 'War on Terror' thesis rather than reducing terror and terrorism contribute to their intensification (Spence 2005). Similarly, the allocation of funding to policy-oriented research on the topic of international security seems not to have created a more secure world but exactly the opposite (Osella 2008). These apparent paradoxes have increased world insecurity to an alarming degree (Schwartz 2004), and this seems to reveal that the 'War on Terror' has other objectives rather than ending terrorism (Rockmore $2004)^{12}$. With the aim of keeping those covered, supporters of the 'War on Terror' thesis need the commitment of anthropologists and other social scientists to justify their worldview and the widening of neoliberalism.

11 The same reasoning is used to justify courts in which the accused cannot know the evidence against them. This abuse and others such as the use of torture, which are radically against the Geneva Conventions and the UN Declaration of Human Rights, have been widely reported in Guantanamo Bay and Abu Ghraib.

12 According to Putzel, USA hegemony rests on a fragile economic base (2006). By perpetuating the warfare climate the current Bush administration is "trying to secure continuing American military and economic supremacy on a global scale over the long term" (Leaman 2004: 234). 


\section{periferia \\ Número 8, junio 2008 \\ www.periferia.name}

In order to successfully oppose the mermaid songs of the military it is crucial that anthropologists take history seriously (Price 2002c). A look at the past will show the dangers of research agendas being shaped by military and political needs, as Price has shown analysing the McCarthyism's effects still evident in the discipline today (2004, 2008b). Conversely, anthropologists also need to take into account the dangers of remaining silent, thus perpetuating power relations. What is needed, therefore, is a committed and critical anthropology that talks truth to power without compromising its academic independence and, as Houtman argues, ensures that is actually heard $(2006)^{13}$. Anthropology has to be "strongly committed to supporting political action orientated to producing a more equal and just distribution of global economic resources" (Gledhill 2006). Anthropologists main ethical duty "must be to protect and serve those studied" (Price 2002a: 4), therefore protecting the interests and safety of the peoples who are likely to be victimised by the 'War on Terror'. This could be done by revealing the complexity behind oversimplified explanations and by de-exoticising the ones being marginalised as uncivilised, reactionary and anti-modern (Price 2002a).

Indeed, anthropologists "need to maintain a strong critical distance" (Gledhill 2003) from these propositions, and should rather put their efforts in understanding the reasons why people embrace violence, engaging with processes of exclusion, humiliation and discrimination (Keen 2006). According to that, the role of professional associations of anthropologists is critical, as they are the best place to discuss dilemmas that affect the whole community of professionals in a "broader and constantly evolving dialogue that will address changing scenarios and new dilemmas as they arise" (Gledhill 2003).

In the light of current debates on ethics, we have to keep asking ourselves what is anthropology about and what is it for. It is known that in the past anthropology has helped to justify colonialism and the 'War on Communism'. Now it depends on committed and critical anthropologists that it does not justify the current 'War on

13 This is not to say that anthropology has not to inform security policy, but that it does so from its independence denouncing government agencies that "expand the kind of research that might feed into their policy-making" (Houtman 2006: 3). 


\section{periferia}

\section{Número 8, junio 2008}

www.periferia. name

Terror' and the ones that might come after that. As Price puts it, "we need to choose carefully the ways that we will use anthropology in this current war, for it seems likely that it will be used one way or another" (Price 2002a: 5). Let us work for it to be used as a tool to build a more equal and just world.

\section{Bibliography}

American Anthropological Association (1971). Principles of Professional Responsibility, in Eric Wakin. 1992. Anthropology goes to War. Professional Ethics \& Counterinsurgency in Thailand. Madison: Centre for Southeast Asia Studies. University of Wisconsin-Madison.

American Anthropological Association (1990). General Principles of Professional Responsibility, in Eric Wakin. 1992. Anthropology goes to War. Professional Ethics \& Counterinsurgency in Thailand. Madison: Centre for Southeast Asia Studies. University of Wisconsin-Madison.

American Anthropological Association (1998). Code of Ethics. Available on http://www. aaanet.org. (10 ${ }^{\text {th }}$ May 2008).

American Anthropological Association (2006). "Resolutions on Iraq and torture advanced at AAA business meeting." Available on http://www.aaanet.org. (10 ${ }^{\text {th }}$ May 2008).

American Anthropological Association (2007). "Statement-on-HTS". Available on http://dev.aaanet.org/issues/policy-advocacy/Statement-on-HTS.cfm (30 ${ }^{\text {th }}$ May 2008).

Association of Social Anthropologists of the UK and Commolwealth (1987). Ethical Guidelines for Good Research Practice. Available on http://www.asa.anthropology.ac.uk. (10 $10^{\text {th }}$ May 2008).

Association of Social Anthropologists of the UK and Commolwealth (1999). Ethical Guidelines for Good Research Practice (revised version). Available on http://www.asa.anthropology.ac.uk. (10 ${ }^{\text {th }}$ May 2008).

Baty, Phil. (2005). ClA outrages UK academics by planting spies in classroom. The 


\section{periferia}

Número 8, junio 2008

www.periferia. name

Times Higher Education Supplement (Published: 03 June 2005). Available on http: //www.thes.co.uk/current_edition/story. aspx?story_id=2022341\&window_type $=$ print. $\left(10^{\text {th }}\right.$ May 2008).

Baty, Phil. (2006). "ife-risking 'spy' plan pulled" The Times Higher Education Supplement (Published: 20 October 2006). Available on http://www.thes.co.uk/search/story.aspx?story_id=2033290. (10 $10^{\text {th }}$ January 2007). British Broadcast Corporation (2005). Fears over CIA 'university spies'. (Published: Thursday 2 June 2005). Available on http://news.bbc.co.uk/2/hi/uk_news/education/4603271.stm. (10 ${ }^{\text {th }}$ J anuary 2007). Beall, Jo; Goodfellow, Thomas \& Putzel, James (2006). Policy Arena. Introductory Article: on the Discourse of Terrorism, Security and Development. Journal of International Development 18: 51-67.

Boas, Franz (1919). Scientists as spies. The Nation. (Published: 16 October 1919). Caplan, Pat (2003). Anthropology and Ethics. In Caplan, Pat (ed.) The Ethics of Anthropology. Debates \& Dilemmas. London: Routledge. 1-33.

Central Intelligence Agency. (n.d.) "The Pat Roberts Intelligence Scholars Program (PRISP)". Available on https://www.cia.gov/careers/jobs/PRISP.html. (10 ${ }^{\text {th }}$ January 2007).

Dean, Bartholomew (2005). The Ethics of Spying. Responses to F. Moos, R. Fardon and H. Gusterson (AT21[3]). Anthropology Today 21 (4): 20-21.

ERSC. (2006). Statement from ERSC regarding ‘Combating Terrorism by Countering Radicalisation'. Availableon

http://www.esrcsocietytoday.ac.uk/ESRCI nfoCentre/opportunities/current_funding_ opportunities/radicalisation. aspx?Componentl $d=17021 \&$ SourcePagel $d=5964\left(10^{\text {th }}\right.$ January 2007).

Fardon, Richard (2005). Anthropologists as Spies. A response to 'ClA seeks anthropologists', news item in AT 20[4]. Anthropology Today 21 (3): 25-26.

Fluehr-Lobban, Carolyn (1991). Ethics and Anthropology in the 1990s and beyond. In Carolyn Fluehr-Lobban (ed.) Ethics and the Profession of Anthropology. Dialogue 


\section{periferia}

Número 8, junio 2008

www.periferia.name

for a New Era. Philadelphia: University of Pennsylvania Press. 213-236.

Gledhill, John (1994). Power and its disguises. London: Pluto.

Gledhill, John (2003). "Our new initiative on ethics: a statement from the Chair". Available on http://www.theasa.org/ethics.htm. (10 ${ }^{\text {th }}$ January 2007).

Gledhill, John (2006). "On the Moos controversy". Available on http://www.theasa.org/ethics/ethics_blog_prisp.htm. (10 ${ }^{\text {th }}$ J anuary 2007).

Glenn, David (2005). Cloak and Classroom. The Chronicle of Higher Education. (Published: 25 March 2005). Available on http://chronicle.com/free/v51/i29/29a01401.htm. (10 J J anuary 2007).

Goodman, Alan H. (2002). "Engaging with National Security". Available on http://www. aaanet.org/press/an/0206/goodman.html. (10 ${ }^{\text {th }}$ J anuary 2007).

Gusterson, Hugh (2003). Anthropology and the military - 1968, 2003, and beyond?. Anthropology Today 19 (3). 25-26.

Gusterson, Hugh (2005a). Anthropologists as Spies. A response to 'ClA seeks anthropologists', news item in AT 20[4]. Anthropology Today 21 (3): 26.

Gusterson, Hugh (2005b). The Ethics of Spying. A response to B. Dean, AT 21[4]. Anthropology Today 21 (5): 21.

Houtman, Gustaaf (2006). Double or quits. Anthropology Today 22 (6): 1-3.

Howell, Jude (2006). The Global War on Terror, Development and Civil Society. J ournal of International Development 18: 121-135.

Keen, David (2006). War Without End? Magic, Propaganda and the Hidden Functions of Counter-Terror. J ournal of International Development 18: 87-104.

Keenan, Jeremy (2006). Conspiracy theories and 'terrorists'. How the 'war on terror' is placing new responsibilities on anthropology. Anthropology Today 22 (6): 4-9.

Kurtz, Stanley (2005). Who will defend the defenders?. The academy takes aim at the Pat Roberts Intelligence Scholars Program. National Review Online (Published 31

March 2005).

Available

on 


\section{periferia}

Número 8, junio 2008

www.periferia.name

http://www. nationalreview.com/script/printpage.p?ref=/kurtz/kurtz200503310747. asp. (10 $0^{\text {th }}$ January 2007$)$.

Leaman, George (2004). Iraq, American Empire, and the War on Terrorism. Metaphilosophy 35 (3): 234-248.

Moos, Felix (2005). Anthropologists as Spies. A response to 'ClA seeks anthropologists', news item in AT 20[4]. Anthropology Today 21 (3): 25.

Moos, Felix (n.d.) "Some Thoughts on Anthropological Ethics and Today's Conflicts". Available on http://www.aaanet.org/press/an/infocus/prisp/moos.htm. $\quad\left(10^{\text {th }}\right.$ January 2007).

McFate, Montgomery (2005). Antropology and Counterinsurgency. The Strange Story of their Curious Relationship. Military Review, March-April: 24-38.

Nas, Peter J.M. (2005). The Ethics of Spying. Responses to F. Moos, R. Fardon and H. Gusterson (AT21[3]). Anthropology Today 21 (4): 19-20.

Network of Concerned Anthropologists (2008). Pledge of Non-participation in Counter-insurgency. Available on http://concerned.anthropologists. googlepages.com/internationalpledge ( $30^{\text {th }}$ May 2008).

Nuti, Paul J. (n.d.) "The Pat Roberts Intelligence Scholars Program: FAQs". Available on http://www.aaanet.org/press/an/infocus/prisp/nuti-faqs.htm. $\quad\left(10^{\text {th }}\right.$ J anuary 2007).

Osella, Filippo (2008) "From war on terror to "global security'". Available on http://blog.theasa.org/?p=52 (30 $30^{\text {th }}$ May 2008).

Price, David H. (2002a) Past wars, present dangers, future anthropologies. Anthropology Today 18(1): 3-5.

Price, David H. (2002b) Lessons from Second World War anthropology. Peripheral, persuasive and ignored contributions. Anthropology Today 18 (3): 14-20.

Price, David H. (2002c) Interlopers and Invited Guests: On Anthropology's Witting and Unwitting Links to Intelligence Agencies. Anthropology Today 18(6): 16-21.

Price, David H. (2004) Threatening anthropology: McCarthyism and the FBI's 


\section{periferia}

Número 8, junio 2008

www.periferia. name

surveillance of activist anthropologists. London, Durham, N.C.: Duke University Press.

Price, David H. (2005a). “Exposing the Pat Roberts Intelligence Scholars Program. The ClA's Campus Spies". Counterpunch (Published: 12/13 March 2005). Available on http://www. counterpunch.org/price03122005.html. (10 $0^{\text {th }}$ January 2007).

Price, David H. (2005b). "ClA Skullduggery in Academia. Carry On Spying (or Pay Us Back at the Rate of 2,400 Per Cent)". Counterpunch (Published: 21/22 March 2005). Available on http://www.counterpunch.org/price05212005.html. $\left(10^{\text {th }}\right.$ January 2007).

Price, David H. (2006a). Anthropology and spying. A reply to Niel SebagMontefiore. Anthropology Today 22 (1): 21.

Price, David H. (2006b). "American Anthropologists Stand Up Against Torture and the Occupation of Iraq". Counterpunch (Published: 20 November 2006). Available on http://www. counterpunch.org/price11202006.html. (10 $10^{\text {th }}$ January 2007).

Price, David H. (2008) “War, Counterinsurgency, Resistance \& Anthropological Ethics". Available on http://blog.theasa.org/?p=42 (30 ${ }^{\text {th }}$ May 2008).

Price, David H. (2008b) Anthropological Intelligence: The Deployment and Neglect of American Anthropology in the Second World War. London, Durham, N.C.: Duke university Press.

Putzel, James. (2006). "Cracks in the US Empire: Uniteralism, the 'War on Terror' and the Developing World". Journal of International Development 18: 69-85.

Rockmore, Tom (2004). On the So-Called War on Terrorism. Metaphilosophy 35 (3): 386-401.

Schwartz, Joseph M. (2004). Misreading Islamist Terrorism: The "War Against Terrorism" and Just-War Theory. Metaphilosophy 35 (3): 273-302.

Sebag-Montefiore, Niel (2006). Anthropology and spying. A response to David H. Price (AT 21[6]). Anthropology Today 22 (1): 21.

Silverman, Sydel. (2000). Ethical Dilemmas. What's New, What's Not. Annals of the 


\section{periferia}

Número 8, junio 2008

www.periferia.name

New York Academy of Sciences: 211-215.

Solovey, Mark. (2001). Project Camelot and the 1960s Epistemological Revolution:

Rethinking the Politics-Patronage-Social Science Nexus a Social Studies of Science 31 (2): 171-206.

Sooben, Phil (2006). Double or quits: A response from the ESRC. Anthropology Today $22(6): 3$.

Spence, Keith (2005). World Risk Society and War Against Terror. Political Studies 53: $284-302$.

Van Ufford, Philip Q. and Giri, Ananta K. (eds.) (2003). A Moral Critique of Development. In Search of Global Responsibilities. London: Eidos.

Wakin, Eric (1992). Anthropology goes to War. Professional Ethics \& Counterinsurgency in Thailand. Madison: Centre for Southeast Asia Studies. University of Wisconsin-Madison.

Wax, Murray L. (2003). Defending the nation? Ethics and anthropology after 9/11. Anthropology Today 19 (3): 23-24.

Whisson, Michael (2000). A response to the debate so far, AT 21 [3-4]. Anthropology Today 21 (5): 22.

\footnotetext{
${ }^{1}$ Send any correspondence to: Addaia.Marrades@uab.cat
} 